\title{
PHYTOCHEMICAL ANALYSIS, ANTIOXIDANT (DNA NICKING ASSAY) AND ANTIBACTERIAL ACTIVITIES OF MORUS NIGRA L. FRUITS SECONDARY METABOLITES
}

\author{
Najlaa Kadhim Issa ${ }^{\mathrm{a}, *}$, and Rihan Saadi Abd-Aljabar ${ }^{\mathrm{b}}$ \\ ${ }^{\text {a }}$ Dept. of Chemistry, College Science, University of Duhok, Duhok, Kurdistan Region, Iraq - najlaa.issa@uod.ac \\ ${ }^{\mathrm{b}}$ Dept. of Chemistry, Faculty of Science University of Zakho, Zakho, Kurdistan Region, Iraq
}

Received: Jan. 2017 / Accepted: Apr. 2017 / Published: Jun. 2017

https://doi.org/10.25271/2017.5.2.368

\begin{abstract}
:
The present study was carried out to identify the chemical composition of ethanol, flavonoid and anthocyanin extracts of Morus nigra fruits. The results revealed the presence of carbohydrates, glycosides, phenolic compounds and the absence of alkaloids, saponins, free amino acids, proteins and tannins. TLC and column chromatography techniques were used to separate and purify the anthocyanin pigment from anthocyanin extract which is then subjected to acid hydrolysis to obtain the anthocyanidin pigment (a). Many techniques were also employed to confirm pigment (a) chemical structure including (TLC, UV-Visible and IRSpectroscopy). According to the forgoing analytical results, the proposed structure for the isolated pigment (a) is cyanidin pigment. DNA nicking assay has been used to evaluate the ability of the prepared extracts and pigment (a) to prevent DNA nicking caused by free radicals generated from Fenton's reagent. The highest DNA protective effect was achieved in anthocyanin extract followed by pigment (a) and their effects were identical to the positive control (cyanidin chloride). Antibacterial activities of all extracts and pigment (a) were performed against the growth of two standards and pathogenic G+ and G- bacteria. The results indicated that all plants extracts showed more potent activity against standard bacteria strains than pathogenic ones.
\end{abstract}

KEYWORDS: Morus nigra, Flavonoid, Anthocyanin, Cyanidin, DNA nicking, Antibacterial activity.

\section{INTRODUCTION}

It is estimated that there are about 250,000 to 500,000 plant species on earth. Plants produce large and diverse groups of molecules that are involved in the adaptation of plants to their environment. In general, the term secondary metabolites had been used to refer to these groups of compounds (Makkar and Becker, 2007). Plant polyphenols are aromatic hydroxylated compounds, which are considered as natural antioxidants responsible for many colors, aromas and flavors characteristics of vegetables, fruits, herbs and beverages. Many food sources form a significant portion of our diet which is among the most potent and therapeutically useful bioactive substances. Flavonoids are one class of polyphenols present at high concentrations in the epidermis of leaves and the skin of various fruits and have important and varied roles as secondary metabolites. Flavonols are very widely distributed in plants; they act as co-pigment to anthocyanin in petals and leaves of higher plants (Harborne, 1984). On the other hand, anthocyanins are widely dispersed throughout the plant kingdom; responsible for most of the red, pink, purple, and blue pigments found in roots, stems, leaves, flowers, seeds, and fruits (Gould et al., 2009). Anthocyanins consist of an aglycone (anthocyanidin), sugar and, in many cases, acyl group which referred to as acylated anthocyanin. Although light is essential for the biosynthesis of anthocyanins, it is also accelerates their degradation (Rein, 2005).

The antioxidant activity of phenolic compounds is mainly attributed to their redox properties, which can play an important role in absorbing and neutralizing free radicals, quenching singlet and triplet oxygen, or decomposing peroxides (Harborne, 1984; Crozier et al., 2006). They can prevent some oxidation-related diseases such as atherosclerosis, cardiovascular, neurodegenerative and cancer diseases (Sun et al., 2009).

The co-pigmentation of anthocyanin can be simple phenols such as catechin, flavanol, chlorogenic acid, caffeic acid and rutin or polyphenols, such as tannins (Castaeda-Ovando et al., 2009). The co-pigmentation of anthocyanin can also be resulted from the interaction with DNA which was illustrated by Sarma and Sharma (1999). They found that calf thymus DNA (ctDNA) and cyanidin can form a cyanidin-DNA co-pigmentation complex as shown in Figure (1), which displayed a 15-20 nm bathochromic shift. Cyanidin-DNA co-pigmentation may be a possible defense mechanism against the oxidative damage of DNA (Sarma and Sharma, 1999).

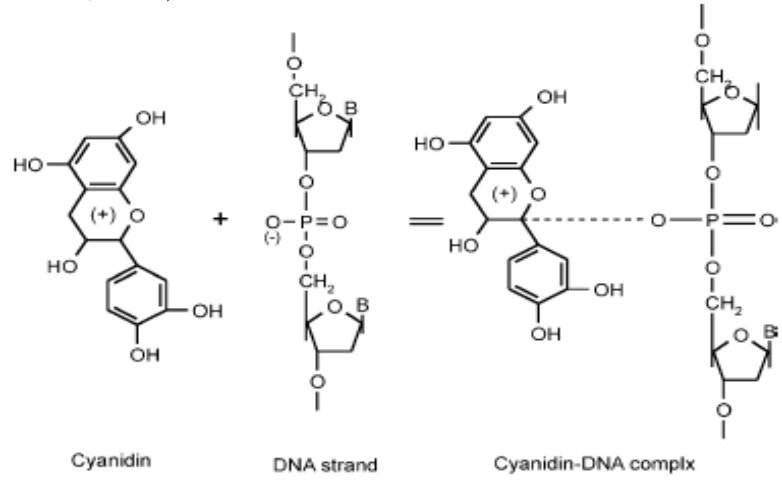

Figure 1. Cyanidin-DNA co-pigmentation

Mulberry belongs to the genus Morus of the family Moraceae. Mulberry trees have been used historically for leaf yield in sericulture. In addition, their fruits have been used in folk

\footnotetext{
* Corresponding author
} 
medicine (especially in Chinese medicine) to treat diabetes, hypertension, anemia and arthritis (Kumar and Chauhan, 2008). Black mulberry fruits are used for treating mouth lesions in Turkey. Recently, red and black mulberries have gained an important position in the food industry due to the presence of anthocyanins (Ozgen et al., 2009).

The literature revealed little information on phytochemical constituents of black mulberry fruits Morus nigra L. prevailed in Kurdistan Region of Iraq. Thereby, this study was conducted to determine the phytochemical constituents of black mulberry fruit extracts. The work includes the evaluation of flavonoid and anthocyanin profiles using HPLC techniques and identification of cyanidin pigment isolated from anthocyanin extract. Antioxidant activity using DNA nicking assay was performed as well as assessment of antibacterial activity against standard and pathogenic bacterial strains of the prepared extracts and the isolated pigment.

\section{MATERIALS AND METHODS}

\subsection{Collection of Plant Materials}

Black mulberry Morus nigra L. fruits were collected on June, 2008 from Duhok-dam, Duhok city- Kurdistan Region of Iraq. The ripe fruits were kept in plastic containers at $-10^{\circ} \mathrm{C}$ until being used (Pantelidis et al., 2007; Spada et al., 2008). The plant was botanically authenticated in Agriculture College -Forestry Department, University of Duhok.

\subsection{Chemicals}

All chemicals used were of analytical grade. Aluminum chloride hexahydrate, amyl alcohol, ferric chloride and methanol were obtained from Ltd Company. Chlorogenic acid, cyanidin chloride, isoqurecetin dihydrate, kampherol, rutin hydrate and qurecetin dihydrate were obtained from ROTH company and others were obtained either from Fluka or Sigma chemicals companies.

\subsection{Preparation of Extracts}

2.3.1 Ethanol Extract: Ethanol extract (Eth. ext.) of black mulberry fruits was prepared following the method of Laleh et al., (2006). Thirty grams of black mulberry fruits were mixed with $200 \mathrm{ml}(70 \%)$ ethanol using electrical blender and the mixing was assisted with shaker water bath for $4 \mathrm{~h}$ at $40{ }^{\circ} \mathrm{C}$. The mixture was filtrated by filter paper (Whattman No.40) and the filtrate was concentrated by evaporation using rotary evaporator to afford 7 grams dark-reddish color extract.

2.3.2 Flavonoid Extract: The Flavonoid extract (F. ext.) of black mulberry fruits was prepared as discussed below (Peach et al., 1955; Harborne, 1984; Andersen and Markham, 2006). Five grams of the alcoholic extract were dissolved in $100 \mathrm{ml}$ of distilled water, then $125 \mathrm{ml}$ of $(1 \%)$ aqueous lead acetate was added with stirring for $5 \mathrm{~min}$ and the solution was left for $2 \mathrm{~h}$ to complete precipitation. Filtration was done by (Whattman No. 40) and the violet-pink filtrate was concentrated by rotary evaporator to obtain solid violet-pink material which has been dissolved later in absolute methanol. Fifty $\mathrm{ml}$ of $(1 \%)$ lead acetate in methanol was then added with stirring for few minutes. The solution was left to complete precipitation for $2 \mathrm{~h}$.

The mixture was filtrated using Buchner funnel and the violet precipitate was washed once with $10 \mathrm{ml}$ distilled water, then with $10 \mathrm{ml}$ absolute methanol, and finally 3 times with $10 \mathrm{ml}$ ethyl acetate. The violet precipitate was left to dry in dark at room temperature. The dry precipitate was dissolved in a mixture of $[25 \mathrm{ml}$ acetone $+5 \mathrm{ml}(2 \mathrm{M} \mathrm{HCl})]$ with shaking, and then was left till complete precipitation of lead acetate. The supernatant was separated and evaporated under vacuum at $40^{\circ} \mathrm{C}$ using rotary evaporator. Light -reddish viscous extract was obtained (1.56 grams).

2.3.3 Anthocyanin Extract: Twenty five grams of black mulberry fruits were mixed with $50 \mathrm{ml}$ of $(1 \% \mathrm{HCl}$ in methanol) using electrical blender for $5 \mathrm{~min}$. The mixture was transferred to dark conical flask and placed in an ice bath with stirring for $12 \mathrm{~h}$. The mixture was filtrated by a Buchner funnel and the filtrate was taken to dryness in dark at room temperature. The obtained extract was washed twice with $25 \mathrm{ml}$ acidified methanol; filtrated through filter paper (Whattman No. 40) and the filtrate was dried in dark at room temperature to obtain 2.44 grams reddish-brown viscous (A. ext.) (Harborne, 1984; Schofs, 2004; Andersen and Markham, 2006).

\subsection{Phytochemical Analysis}

Preliminary qualitative tests were carried out on the foregoing prepared extracts following the method of Harbone (1984) for the presence of various classes of compounds such as alkaloids, flavanoids, tannins, phenolic compounds, saponins, glycosides, carbohydrates, amino acids and proteins.

2.5 Chromatographic Techniques for Isolation of Anthocyanidin Pigment (Pig. A) from Anthocyanin Extract:

Different solvent systems were tested as mobile phase in TLC technique using silica gel TLC plates to identify the number of components and their $\mathrm{R}_{\mathrm{f}}$ values in A. ext. (Harborne, 1984; Mingwei et al., 2006). The best solvent system was (n-amyl alcohol: formic acid) by the ratio (5:1). The open column was filled up with a slurry of silica gel (200-400 mesh size) as a stationary phase and (n-amyl alcohol: formic acid) by the ratio (5:1) as a mobile phase was used for the separation of anthocyanin pigment from A. ext. (Schofs, 2004). The fractions on the top of column was collected and tested by TLC, the tubes sample which have the same $R_{f}$ value were collected and left to dry at dark room temperature to get a violet viscous anthocyanin pigment.

Anthocyanin pigment was subjected to acid hydrolysis by $2 \mathrm{M}$ $\mathrm{HCl}$ for $40 \mathrm{~min}$ at a boiling water bath, and then the colored extract was cooled and extracted with ethyl acetate $(2 \times 10 \mathrm{ml})$. The aqueous layer was extracted with amyl alcohol $(2 \times 10 \mathrm{ml})$. The amyl alcohol layer was separated and dried in dark at room temperature to obtain pink-violet anthocyanidin pigment which is referred to as Pig. (a) (Harborne, 1984; Zhang et al., 2005; Andersen and Markham, 2006).

\subsection{High Performance Liquid Chromatography (Hplc)}

HPLC technique (Smart line manager 5000, smart line column the most at 4000, smart line HPLC pumps 1000, Knauer advanced scientific instrument, Germany) was applied to identify the flavonoid components that present in F. ext. Acetonitrile: phosphoric acid $(0.1 \%)$ by the ratio $(25: 75)$ was used as a mobile phase. Flavonoid extract and standards were first filtered through a $0.22 \mu \mathrm{m}$ sterile polytetrafluroethylene filter (Millipore filter), then injected through the Eurospher C18 $(250 \mathrm{~cm} \mathrm{x} 4.6 \mathrm{~mm}$ i. d) with a flow rate of $1 \mathrm{ml} / \mathrm{min}$. The samples were detected using UV detector 2500 at $\lambda$ max $=368 \mathrm{~nm}$.

HPLC ((Shimadzu, SPD-20A, supelco column RP18, LC20AT HPLC pump, Japan) was also performed for A. ext. and Pig. (a) using 2 solvent systems; solvent I (15\% acetic acid and $1.5 \%$ phosphoric acid) in water and solvent II (( $100 \%$ acetonitrile). The solvent mixture was established at $90 \%$ solvent I and $10 \%$ solvent II. The samples and cyanidin chloride were injected through the 
Supelco C18 ( $25 \mathrm{~cm} \times 4.6 \mathrm{~mm}$ i. d) with a flow rate of $1.5 \mathrm{ml}$ $/ \mathrm{min}$ and detected by UV-VS detector at $\lambda \max =540 \mathrm{~nm}$.

\subsection{Spectrophotometric Analysis}

Ultra Violet-Visible Spectra for Pig. (a) was recorded at (200-800 nm) using UV-VS Spectrophotometer. Visible Spectra was also used to identify catecol nucleus in Pig. (a) by noticing a bathochromic shift in its visible spectrum in the presence of aluminum chloride (Harborne, 1984). IRSpectrum was recorded for Pig. (a) with the range of (600$4000 \mathrm{~cm}^{-1}$ ) using potassium bromide disc (Ming-wei et al., 2006).

\subsection{Antioxidant Activity (DNA Nicking Assay)}

Genomic DNA of Escherichia coli HB101 bacteria which harbor the plasmid pBR322 was isolated according to the method reported by (Lema et al., 1994). The optical density (O.D.) of DNA solution (20 $\mu 1$ DNA sample, $1980 \mu 1$ Tis EDTA buffer) was measured at wave length of 260 and 280 $\mathrm{nm}$. The ratio between the reading at $260 \mathrm{~nm} / 280 \mathrm{~nm}$ provides an estimation of the purity of nucleic acid (Sambrook et al., 1989).The DNA concentration in the solution was calculated according to the following formula:

DNA $(\mu \mathrm{g} / \mu \mathrm{l})$

$=\frac{0 . D 260 \times \text { dilution factor } \times 50 \mu \frac{\mathrm{g}}{\mathrm{ml}}}{100}$

DNA nicking assay as described by (Yenug et al., 2002; Lee et al., 2002) was performed using pBR322 plasmid DNA. The reaction was conducted in an eppendrof tube containing $1 \mu \mathrm{L}$ of $0.5 \mu \mathrm{g}$ genomic DNA, and $10 \mu \mathrm{L}$ of Fenton's reagent ( $3 \mu \mathrm{L}$ of $2 \mathrm{mM} \mathrm{FeSO}_{4}, 3 \mu \mathrm{L}$ of $(30 \%) \mathrm{H}_{2} \mathrm{O}_{2}, 2 \mu \mathrm{L}$ of $50 \mathrm{mM}$ ascorbic acid and $2 \mu \mathrm{L}$ of phosphate buffer 7.4) was mixed. Two $\mu \mathrm{L}$ of each of the samples $(500 \mu \mathrm{g} / \mathrm{ml})$ Eth. ext., F. ext., A. ext. and Pig. (a) as well as the positive controls (rutin, tannic acid and cyanidin chloride) were added. Sample containing $0.5 \mu \mathrm{g}$ genomic DNA (without Fenton's reagent) in $15 \mu \mathrm{L}$ TE buffer was also used as a control. Incubation at $37^{\circ} \mathrm{C}$ for $1 \mathrm{~h}$ was done, and then $1 \mu \mathrm{L}$ of 0.5 EDTA (pH 8.0) was added to stop the reaction. Five $\mu \mathrm{L}$ of loading buffer were mixed with each tested sample, and then samples were loaded carefully to the individual wells onto $0.8 \%$ agarose gel and electrophoresed followed by ethidium bromide staining. Photographing was done using digital camera (Maniatis et al., 1982).

\subsection{Antibacterial Activity}

The antibacterial activity of black mulberry fruits extracts [Eth., F., A. ext. and Pig. (a)] were tested against 2 strains of standard bacteria namely (Staphylococcus aureus NCTC 6571 and Escherichia coli NCTC 5933) and 2 strains of pathogenic bacteria namely( Staphylococcus aureus and Escherichia coli) using agar -well diffusion method (Park et al., 1997; Turkoglu et al., 2007).

\section{RESULTS AND DISCUSSION}

\subsection{Results of Phytochemical Tests}

Phytochemical screenings of the prepared extracts are shown in Table 1. Preliminary phytochemical screening for all extracts revealed the presence of carbohydrates, glycosides, flavonoids and phenolic compounds and the absence of alkaloids, saponins, free amino acids and proteins except Eth. ext. which poses saponins and tannins. These results are consistent with the fact that species of Moreacea family are a well-recognized source of secondary metabolites like flavonoids and anthocyanin which impart sweaty flavor to their fruits (Ozgen et al., 2009).

Table 1. Phytochemical analysis of Morus nigra Eth., F. and A. Extracts

\begin{tabular}{|c|c|c|c|c|}
\hline $\begin{array}{c}\text { Phytochemical } \\
\text { test }\end{array}$ & $\begin{array}{l}\text { Eth. } \\
\text { ext. }\end{array}$ & $\begin{array}{l}\text { F. } \\
\text { ext. }\end{array}$ & $\begin{array}{l}\text { A. } \\
\text { ext. }\end{array}$ & Notes \\
\hline $\begin{array}{l}\text { Drageendroff's } \\
\text { reagent }\end{array}$ & - & - & - & No alkaloids \\
\hline $\begin{array}{c}\text { Wagner's } \\
\text { reagent }\end{array}$ & - & - & - & No alkaloids \\
\hline Hager's reagent & - & - & - & No alkaloids \\
\hline $\begin{array}{l}\text { Mercury } \\
\text { chloride }\end{array}$ & + & - & - & $\begin{array}{c}\begin{array}{c}\text { Presence of } \\
\text { saponins }\end{array} \\
\end{array}$ \\
\hline Ninhydrin test & - & - & - & $\begin{array}{c}\text { Absence of free } \\
\text { amino acids }\end{array}$ \\
\hline Biuret test & - & - & - & $\begin{array}{c}\text { Absence of } \\
\text { proteins. }\end{array}$ \\
\hline Molish test & + & + & + & $\begin{array}{c}\text { Presence of } \\
\text { carbohydrates. }\end{array}$ \\
\hline $\begin{array}{l}\text { Benedict's } \\
\text { reagent } \\
\text { (before } \\
\text { hydrolysis) }\end{array}$ & + & + & + & $\begin{array}{l}\text { Presence of } \\
\text { reducing sugars. }\end{array}$ \\
\hline $\begin{array}{c}\text { Benedict's } \\
\text { reagent } \\
\text { (after } \\
\text { hydrolysis) }\end{array}$ & + & + & + & $\begin{array}{l}\text { Presence of } \\
\text { glycosides. }\end{array}$ \\
\hline $\begin{array}{c}\text { Alcoholic KOH } \\
(5 \mathrm{~N})\end{array}$ & + & + & + & $\begin{array}{l}\text { Presence of } \\
\text { flavonoids. }\end{array}$ \\
\hline
\end{tabular}

\subsection{TLC and Column Chromatography}

TLC technique used for A. ext. gave 5 spots which indicated the presence of 5 components that could be separated by column chromatography technique. The best selected solvent system was [n-amyl alcohol: formic acid (5:1)]. Column chromatography was the best technique used for isolation of pure pigments from A. ext. due to its ability to isolate different anthocyanins from A. ext. silica gel (230-400 mesh size) columns which were applied to obtain different pigments (Johnson and Morris, 1996).

Column chromatography which was used for isolation of anthocyanidin pigment from A. ext. gave 5 separated colored layers. According to the color and the $\mathrm{R}_{\mathrm{f}}$ value of the final layer on the top of column; this layer was eluted, separated, dried and subjected to acid hydrolysis to obtain anthocyanin pigment Pig. (a). TLC technique for Pig. (a) using the same mobile phase gave one spot with $R_{f}$ value of 0.068 which was almost the same $R_{f}$ value of standard cyanidin chloride indicating that Pig. (a) was cyanidin pigment.

\subsection{High Performance Liquid Chromatography (HPLC)}

The flavonoid constituents of F. ext. from black mulberry fruits were determined by HPLC. The chromatogram of F. ext. and all standards acquired at $368 \mathrm{~nm}$ are presented in Figure (2) which shows many peaks. Five of these peaks had $R_{t}$ values approximately identical to the $\mathrm{R}_{\mathrm{t}}$ of corresponding standards which indicated the presence of chlorogenic acid $\left(R_{t}=3.15 \mathrm{~min}\right)$, rutin $\left(R_{t}=3.96 \mathrm{~min}\right)$, isoquerctine $\left(\mathrm{R}_{t}=4.43 \mathrm{~min}\right)$, querctine $\left(\mathrm{R}_{\mathrm{t}}=12.10 \mathrm{~min}\right)$ and kaempferol $(\mathrm{R} t=22.21 \mathrm{~min})$ in $\mathrm{F}$. ext. The obtained results were in agreement with reports of Apak et al., (2007) who found that black mulberries were rich source of phenolics such as rutin, kaempferol, quercetin, isoquercetin and chlorogenic acid. The anthocyanin constituents of A. ext. and Pig. (a) were also determined by HPLC. The chromatogram of A. ext. and Pig. (a) recorded at $540 \mathrm{~nm}$ are presented in Figure (3) which revealed the presence of a peak with $R_{t}$ values approximately identical to the Rt of cyanidin chloride standard. 


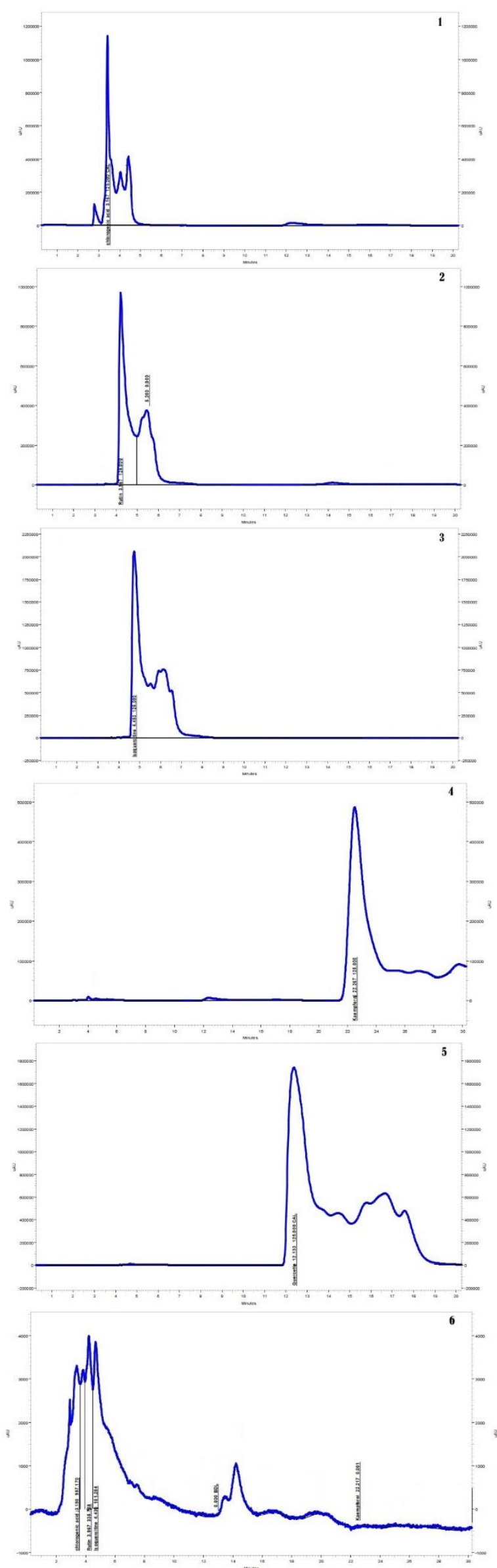

Figure 2. HPLC chromatogram for: (1) Chlorogenic acid, (2) Rutin, (3) Isoquerctine, (4) Kaempferol, (5) Querctine and (6) F. ext.
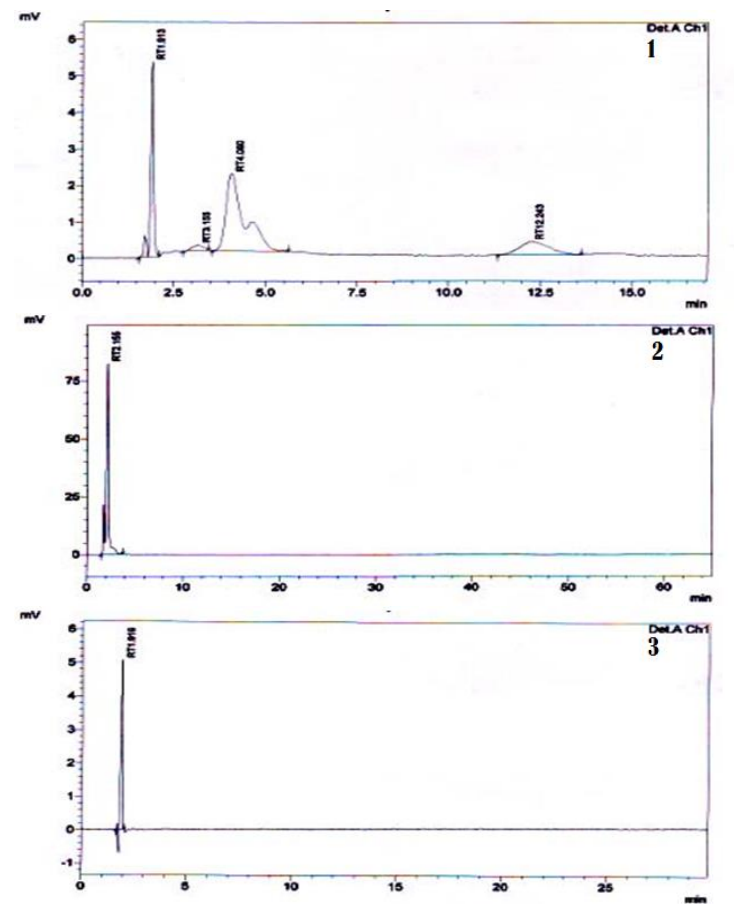

Figure 3. HPLC chromatogram for: (1) A. ext. (2) Pig. (a), (3) Cyanidin chloride standard

\subsection{Spectrophotometric Analysis}

Pigments are able to absorb visible light due to the presence of the chromospheres (Schofs, 2004). The UV spectrum of Pig. (a) as shown in Figure 4 revealed the appearance of 2 absorbance bands at $(228 \mathrm{~nm})$ and $(315 \mathrm{~nm})$ which corresponded to $\pi \rightarrow \pi^{*}$ electron transition of conjugated double bond system and $n \rightarrow \pi^{*}$ from the non-bonding electrons of the oxygen atom to the aromatic $\pi$ system of the B-ring (Vermerris and Nicholoson, 2006).

Visible spectrum of Pig. (a) as shown in Figure 5 revealed absorption band at $(535 \mathrm{~nm})$ which corresponds to $\mathrm{n} \rightarrow \pi^{*}$ transition of the non- bonding electron of the oxygen atom (Silverstien and Morril, 1981). These spectral bands usually appear in similar anthocyanin compounds (Harborne, 1984; Andersen and Markham, 2006). Visible spectrum of Pig. (a) undergoes a bathochromic shift about $15 \mathrm{~nm}$ after the addition of aluminum chloride solution as shown in Figure 6. This shift indicated the presence of vicinal free hydroxyl groups of anthocyanidin pigment in the proposed structure which contained catechol nucleus (Harborne, 1984).

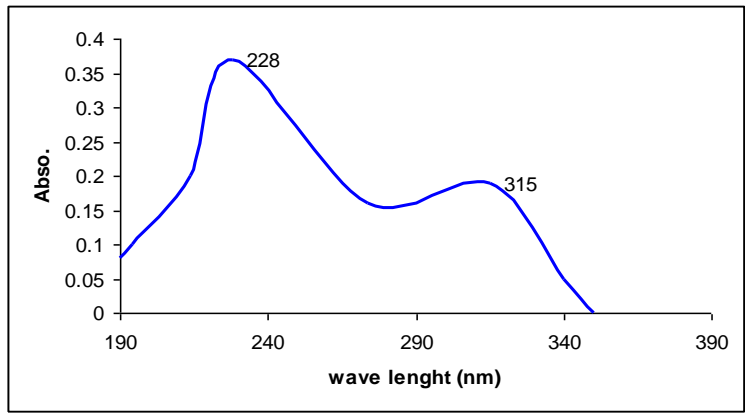

Figure 4. UV-spectrum of Pig. (a) 


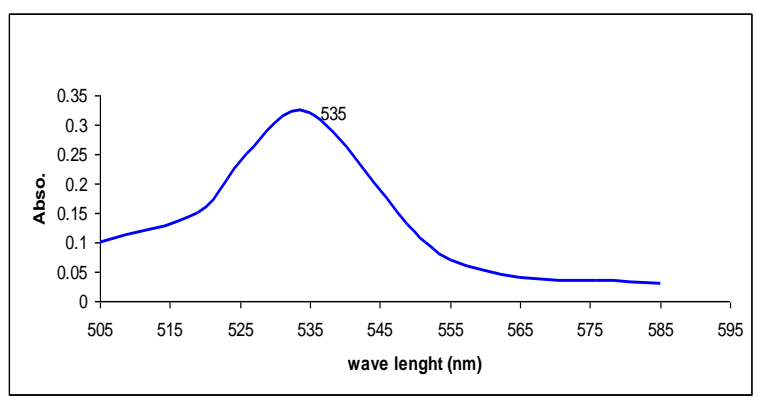

Figure 5. VS spectrum of Pig. (a)

Infrared spectroscopy is useful to determine what functional groups are attached to the basic skeletal structure of the flavonoid molecule. The Infrared spectrum of Pig. (a) as shown in Figure 7 indicated the appearance of strong bands at $3100-3600 \mathrm{~cm}-1$ related to the vibration of hydroxyl bond which indicated the presence of polyphenolic compound.

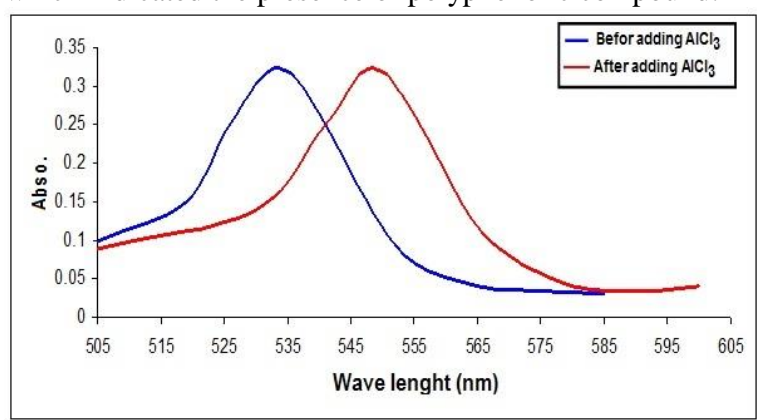

Figure 6. Visible spectrum of catechol nucleus using alcoholic $\mathrm{AlCl}_{3}$

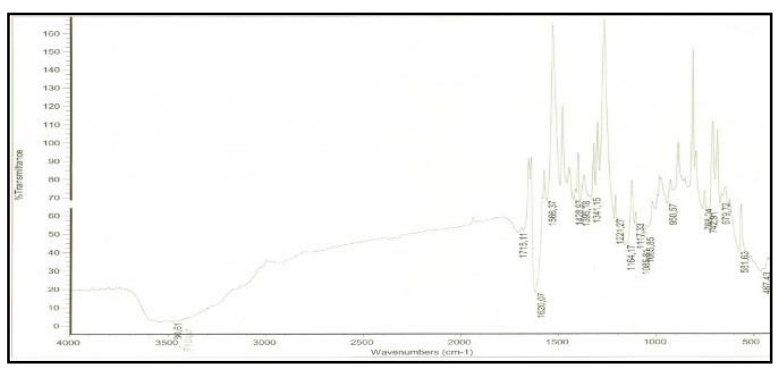

Figure 7. IR-Spectrum for the isolated Pig. (a)

The bond at $1620 \mathrm{~cm}-1$ related to the vibrational bond stretching of $(\mathrm{C}=\mathrm{C})$ conjugated double system in aromatic compound. The band at $1117 \mathrm{~cm}-1$ related to dialkyl ether group $(\mathrm{C}-\mathrm{O}-\mathrm{C})$ bridge indicated the presence of aromatic ether compound (Silverstien and Morril, 1981). Consequently, according to the available data of chromatographic and spectroscopic applied on Pig. (a), one can conclude that the isolated pigment could be cyanidin. This conclusion was confirmed by Lee et al., (2004) who found that mulberries had cyanidin-based anthocyanins, particularly cyanidin-3-glucoside (79\%) and cyanidin-3rutinoside (19\%).<smiles>Oc1cc(O)c2cc(O)c(-c3ccc(O)c(O)c3)[o+]c2c1</smiles>

Figure 8. The proposed structure for Pig. (a)

\subsection{Antioxidant Activity Using DNA Nicking Assay:}

Good yields of genomic DNA were obtained by DNA isolation method, (Lema et al., 1994). The average yields were 18.00 $\mu \mathrm{g} / 30 \mathrm{ml}$ broth culture with purity about (1.64) measured by spectrophotometer ratio A260/A280, which is considered as a high purity. Ratios above 2.0 correspond to RNA contamination, while ratios below 1.6 suggest protein contamination (Sinha et al., 2001). The effects of Eth., F., A. ext. and Pig. (a) as antioxidants on the free radical-induced DNA damage were investigated as shown in Figure 9.

The protective effect can be investigated in both non site specific assay using ascorbic acid -iron- $\mathrm{H}_{2} \mathrm{O}_{2}$-EDTA system and site -specific scavenging assay without EDTA. Lane 2, represent the interaction of $\mathrm{HO}^{*}$ with DNA which was continuously (without addition of EDTA) resulting in a complete DNA damage and showed the presence of a detectable smear of DNA fragments but lane 3 showed that the interaction of $\mathrm{HO}^{*}$ with DNA after incubation for $1 \mathrm{~h}$ was stopped by addition of $0.5 \mathrm{M}$ EDTA as chelating agent causing single strand breaks of super coiled DNA into relaxed open circular state or converted super coiled DNA to linear form by double strand breaks (Larson et al., 1992; Yenug et al., 2002).

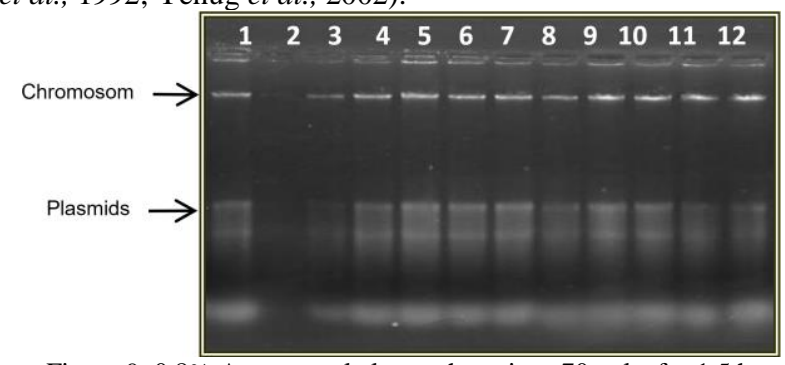

Figure 9. $0.8 \%$ Agarose gel electrophoresis at 70 volts for $1.5 \mathrm{~h}$.

Lanes 1, 6 and 12, genomic DNA + TE buffer

Lane 2, Fenton reagent+ genomic DNA

Lane 3, Fenton reagent+ genomic DNA + 0.5M EDTA

Lane 4, Fenton reagent+ genomic DNA + A. ext. + 0.5M EDTA

Lane 5, Fenton reagent+ genomic DNA+ cyanidin chloride + $0.5 \mathrm{M}$ EDTA

Lane 7 , Fenton reagent+ genomic DNA + tannic acid $+0.5 \mathrm{M}$ EDTA

Lane 8, Fenton reagent+ genomic DNA+ Eth. ext. + 0.5M EDTA Lane 9, Fenton reagent+ genomic DNA+ rutin + 0.5M EDTA

Lane 10, Fenton reagent+ genomic DNA+ F. ext. + 0.5M EDTA Lane 11, Fenton reagent+ genomic DNA + Pig. (a) $+0.5 \mathrm{M}$ EDTA.

In the presence of extracts, the extent of DNA damage could be significantly reduced and the protective effects is clearly appeared (lanes 4, 8, 10 and 11) because antioxidant compounds present in the extract which is considered as good electron donors, may accelerate the conversion of $\mathrm{H}_{2} \mathrm{O}_{2}$ to $\mathrm{H}_{2} \mathrm{O}$ (Shon et al., 2007). These results are due to the interaction of anthocyanins and DNA forming cyanidin-DNA co-pigmentation complex (Sarma and Sharma, 1999). It is concluded that the antioxidant activity is observed in the non- site -specific assay rather than site-specific assay when the same concentration $(500 \mu \mathrm{g} / \mathrm{ml})$ of several extracts were used which implying that the extracts scavenging hydroxyl radical directly rather than chelates metal ion (Duan et al., 2008 and Singh et al., 2009).

\subsection{Antibacterial Activity of Mulberry Fruit Extracts and Pig. (A)}

Black mulberry extracts and Pig. (a) could be used as food preservative, that it can prevent food spoilage due to their antibacterial activity (Radovanovic et al., 2009). The 
antibacterial activity of black mulberry fruit extracts and Pig. (a) are shown in Figure (10) and the inhibition zone diameters are shown in Table 2 . The obtained results revealed that all plant extracts and Pig. (a) had a pronounced effect against the growth of G+ and G- standard strains compared with the pathogenic ones. This could be reasoned to the fact that pathogenic bacteria undergo many mutations and consequently become more resistant to antibiotics. These antibiotics have more potency against bacterial growth than plants extracts.

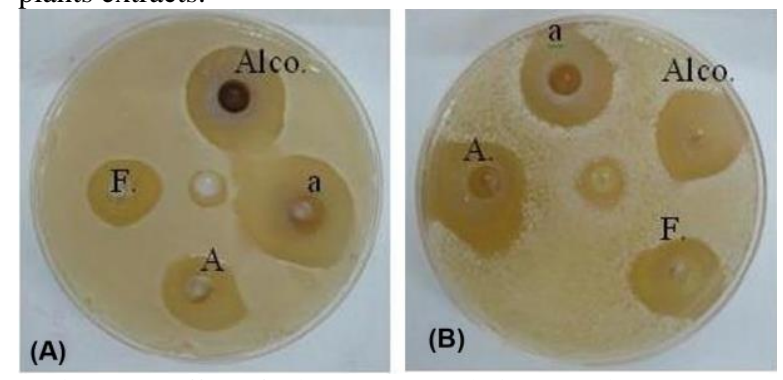

Figure 10. Effect of Eth., F.A. ext. and Pig. (a) at the conc. 100 $\mathrm{mg} / \mathrm{ml}(\mathrm{A})$ : against $S$. aureus $(\mathrm{G}+)$ standard bacteria (B): against $E$. coli (G-) standard bacteria

All plants extracts showed more potent activity against $\mathrm{G}+$ than G- bacteria due to presence of many condensed fat bilayers lipid in the cell membrane of G- bacteria compared with gram positive cell membrane (Radovanovic et al., 2009). Regarding to standard bacterial strains, all plants extracts exhibited various reduction in growth of microorganisms, depending on the extract concentration and the chemical compositions present in the studied plants extracts.

Table 2. Antibacterial activity of Eth., F., A. ext. and Pig. (a) against standard and pathogenic (G+) and (G-) bacterial strains

\begin{tabular}{|c|c|c|c|c|c|}
\hline \multicolumn{2}{|c|}{$\begin{array}{l}\text { Bycteria } \\
\text { Exthets } \\
\& \\
\text { conc.(mg } \\
\text { ml) }\end{array}$} & $\begin{array}{c}\text { S. aureus } \\
\text { (NCTC65 } \\
71)\end{array}$ & $\begin{array}{c}\text { S. aureus } \\
\text { (Pathoge } \\
\text { nic) }\end{array}$ & $\begin{array}{c}\text { E. coli } \\
\text { (NCTC59 } \\
33)\end{array}$ & $\begin{array}{c}\text { E. coli } \\
\text { (Pathoge } \\
\text { nic) }\end{array}$ \\
\hline \multirow{4}{*}{ Eth. } & 25 & 11 & --- & 8 & --- \\
\hline & 50 & 14 & --- & 12 & --- \\
\hline & 75 & 16 & --- & 16 & --- \\
\hline & $\begin{array}{c}10 \\
0\end{array}$ & 18 & 14 & 16 & --- \\
\hline \multirow{4}{*}{ F. } & 25 & 9 & --- & 10 & --- \\
\hline & 50 & 10 & --- & 11 & --- \\
\hline & 75 & 11 & --- & 12 & --- \\
\hline & $\begin{array}{c}10 \\
0\end{array}$ & 12 & --- & 14 & --- \\
\hline \multirow{4}{*}{ A. } & 25 & 10 & --- & 8 & --- \\
\hline & 50 & 12 & --- & 16 & --- \\
\hline & 75 & 14 & --- & 15 & --- \\
\hline & $\begin{array}{c}10 \\
0\end{array}$ & 13 & --- & 17 & --- \\
\hline \multirow{4}{*}{$\begin{array}{l}\text { Pig. } \\
\text { (a) }\end{array}$} & 25 & 8 & --- & 8 & --- \\
\hline & 50 & 12 & --- & 13 & --- \\
\hline & 75 & 6 & --- & 14 & --- \\
\hline & $\begin{array}{c}10 \\
0\end{array}$ & 18 & --- & 16 & --- \\
\hline
\end{tabular}

\section{CONCLUSIONS}

It can be concluded that (F. ext.) is a rich source of flavonoids including chlorogenic acid, rutin, isoquerctine, querctine and kaempferol. Also, A. ex. is a rich source of anthocyanins including cyanidin pigment. The proposed structure for the isolated pigment (a) is cyanidin pigment which was approved by HPLC and UV-Visible techniques. The black mulberry fruits had the potential protective effect to prevent DNA damage, the highest DNA protective effect was achieved in anthocyanin extract followed by Pig. (a) where their effects were identical to the positive control (cyanidin chloride). All plants extracts showed more potent activity against standard bacteria strains than pathogenic ones.

\section{REFERENCES}

Apak, R., K. Guclu, B. Demirata, M. Ozyurek, S. E. Celik, B. Bektasoglu, I. Berker, and D. Ozyurt. (2007). Comparative evaluation of various total antioxidant capacity assays applied to phenolic compounds with the CUPRAC assay. J. Molecules, 12: 14961547.

Banso, A. (2009). Phytochemical and antibacterial investigation of bark extracts of Acacia nilotica. J. Med. Plants Res., 3: 082-085.

Castaeda-Ovando, A., Pacheco-Hernandez, D. 1., Paez- Hernandez, M. E., Rodriguez, J.Z. and Galan -Vidal, C. A. (2009). Chemical studies of anthocyanins: A review, Food Chem., 113: 859871 .

Crozier, A., Clifford, M. N. and Ashihara, H. (2006). In: Plant secondary metabolites: occurrence, structure and role in the human diet. P.1-12.

Duan, X., Genfu, W. and Jiang, Y. (2007). Evaluation of antioxidant properties of Litchi fruit phenolics in relation to pericarp browning prevention. J. Molecules, 12: 759-771.

Gould, K., K. Davies and, C. Winefield. (2009). In: Anthocyanins biosynthesis, functions, and applications. USA, P.90 -198.

Harborne, J. B. (1984). In: Phytochemistry Methods. New York Wiley; P.1-70.

Johnson, T.V. and Morris, J. R. J. (1996). Food Sci. 61. C. F. Schoefs, B. (2004). Determination of pigments in vegetables. $J$. Chrome., 1054: 217-226.

Kumar, V. and S. Chauhan. (2008). Mulberry: Life enhancer. J. Med. Plants Res., 2: 271-278.

Laleh, G. H., H. Frydoonfar, R. Heidary, R. Jameel and S. Zare. (2006). The effect of light, temperature, $\mathrm{pH}$ and species on stability of anthocyanin pigments in four Berberis species. Pakistan J. Nut., 5:90-92.

Larson, R. A., Lloyd, R. E. and Marley, K. A. (1992). Ferric-ion photosensitized damage to DNA by hydroxyl and non hydroxyl radical mechanisms. J. Photochem. Photobiol., 14: 345-357.

Lee, J. C. and Kim, J. (2002). Antioxidant property of an ethanol extract of the stem of Opuntia ficus indica var. Saboten. J. Agr. Food Chem., 50:6490-6496.

Lema, M. W., Brown, A. and Calkins, J. H. (1994). A general method for the extraction of DNA from bacteria. J. Microbial Methods, 19:167-172.

Makkar, H. S. and K. S. Becker. (2007). In: Plant Secondary Metabolites. Germany, P.89 - 97.

Maniatis, T., Fritsch, E. F. and Sambrook, J. (1982). In: Molecular Cloning: A Laboratory Manual, Cold Spring Harbor Laboratory. New York.

Ming-weil, Z., G. Bao-jiang, Z. Rui-fenl, , C. Jian-weil ,W. Zhen-chengl , X. Zhi-hongl, Z. Yanl, and T. Xiao-Junl.(2006). Separation, purification and identification of antioxidant compositions in black rice. Agri. Sci. in China. 5:431-440.

Ozgen, M., S. Serc, and C. Kaya. (2009). Phytochemical and antioxidant properties of anthocyanin-rich Morus nigra and Morus rubra fruits. Scie. Hort., 119: 275-279.

Pantelidis, G. E., M. Vasilakakis, G. A. Manganaris and G. Diamantidis. (2007). Antioxidant capacity, phenol, anthocyanin and ascorbic acid contents in raspberries, blackberries, red currants, gooseberries and cornelian cherries. Food Chem., 102:777-783.

Park, Y. K., Koo, M. H., Ikegaki, M. and Contado, J. L. (1997). Comparison of the flavonoid aglycone contents of Apis 
mellifera propolis from various regions of Brazil. Arquivor de Biologiae Techno, 40:97-106.

Peach, K. and M. V. Tracey. (1955). Modern methods of plant analysis. Springer-Verlag Bertin Germany, 4:367-511.

Radovanovic, A., Radovanovic, B. and Jovancicevic, B. (2009). Free radical scavenging and antibacterial activities of southern Serbian red wines. J. Food Chem., 117: 326-331.

Rein, M. ( 2005). Copigmentation reactions and color stability of berry anthocyanins. Academic Thesis, Faculty of Agriculture and Forestry-University of Helsinki.

Sambrook, J., Fritch, E. F. and Maniatis, T. (1989). In: Molecular Cloning: A Laboratory manual. New York, U.S.A.

Sarma, A.D. and Sharma, R. (1999). Anthocyanin-DNA copigmentation complex: mutual protection against oxidative damage. Phytochemistry, 52: 1313-1318.

Schofs, B. (2004). Determination of pigments in vegetables. $J$. Chrom., 1045: 217-226.

Shon, M. Y., Lee, J. and Choi, J. H. (2007). Antioxidant and free radical scavenging activity of methanol extract of chungkukjang. J.Food Composion and Analysis, 20: 113118.

Silverstien, B. and A. Morril. (1981). In: Spectrometeric identification of organic compound. John Wiley and Sons $3^{\text {rd }}$ ed. New York.

Singh, B. N., Singh, B. R., Singh, R. L., Prakash, D., Singh, D. P. , Sarma, B. K., Upadhyay, G. and Singh, H. B.(2009). Polyphenolics from various extracts/fraction of red onion (Allium cepa) peel with potent antioxidant and antimutagenic activities. J. Food and Chemical Toxicology, 47:1161-1167.

Sinha, R. P., Dautz, M. and Hader, D.P. (2001). A simple and efficient method for the quantitative analysis of thymine dimers in cyanobacteria, phytoplankton and macroalgae. Acta Protozoologica., 40: $187-195$.

Spada, P. D. S. , G. G. N. Souza, G. V. Bortolini, J. A. P. Henriques and M. Salvador.(2008). Antioxidant, mutagenic, and antimutagenic activity of frozen fruits. J. Med. Food, 1 : 144-151.

Sun, J.; Yao, J., Huang, S., Long, X., Wang, J. and Garcia- Garcia, E. (2009). Antioxidant activity of polyphenol and anthocyanin extracts from fruits of Kadsura coccinea (Lem.) A. C. Smith. Food Chem., 117:276-281.

Turkoglu, A., Duru, M. E. and Mercan, N. (2007). Antioxidant and antimicrobial activity of Russula delica Fr: An Edible Wild Mushroom. Eurasian J. of Anal. Chem., 1: 54-67.

Vermerris, W. and R. Nicholoson. (2006). In: Phenolic compounds biochemistry. USA, P.2-15.

Yeung, S. Y., Lan, W. H., Huang, C. S., Lin, C. P., Chan, C. P. and Chang, M. C.(2002). Scavenging property of three cresol isomers against $\mathrm{H}_{2} \mathrm{O}_{2}$, hypochlorite, superoxide and hydroxyl radicals. Food and Chem. Toxicology, 40: 1403-1413.

Zhang, L. and A. L. Demain. (2005). In: Natural products: drug discovery and therapeutic medicine. USA; P.4 -13. 